\title{
SEZ in Africa: Causes of the Crisis and Development Potential
}

\author{
Marina Berdina ${ }^{1},{ }^{*}$ Aleksandr Berdin ${ }^{1}$ \\ ${ }^{1}$ Saint Petersburg State University of Aerospace Instrumentation, Russia \\ "Email: svitkova_marina@mail.ru
}

\begin{abstract}
The relevance of the topic is caused by the fact that the African continent is still both poorly studied and unattractive for most foreign investors. The aim of the study is to determine the main problems in the creation of SEZ in Africa and to analyze possible directions for the effective development of these structures in the region.

As research methods, the authors chose a general scientific methodology based on the works of scientists specializing in the problems of socio-economic development and investment attractiveness of Africa, particularly: T. Farole, W. Angko, J. Akinci, J. Quake, and L. Thompson. The authors also used the data of reports of international organizations devoted to the analysis of the functioning of the SEZs in Africa.

In the course of the study, we obtained results demonstrating the presence of sufficient potential for the successful development of existing zones or for the creation of at least one SEZ in almost every African state in the near future, which will allow countries to develop and provide stable sources of income for the local population involved in the SEZ. Based on the results of the study, we concluded that if Africa is seriously considering adopting a SEZ model for development, it needs an urgent integration of policy adjustments, like urgent and fundamental reforms to change attitudes towards foreign capital in order to stimulate industrialization and promote more active participation of Africa in the worldwide market.
\end{abstract}

Keywords: Special economic zones, Africa, Zones based on natural resources, Investment in Africa.

\section{INTRODUCTION}

The creation and development of special economic zones (SEZ) is one of the trends in the modern world economy. The experience of many countries shows that SEZs are a good tool in the process of economic modernization. Such structures can contribute to the growth of foreign investment, the development of innovations and high-tech production, which is extremely necessary for modern developing countries, especially those belonging to the group of weakly developing ones $[1,2,3]$.

The history of the development of the first free economic zones refers to the period of the emergence of capitalist relations in Europe in the 15th - 16th centuries, but their peak of development coincided with the formation of the global economy and fell on the second half of the 20th century.

A key factor for making a decision and creating SEZs is that they are "delimited geographic areas within the national borders of a country, [where] the rules for doing business are different and often more liberal" [4]. SEZs provides investors such advantages as convinient infrastructure and special customs regimes, for example import and export without tax payment, tax privilege, etc. FEZs' establishment can improve and improve and intensify market processes in host countries and stimulate economic development in such countries.

However, the experience of developing countries in Africa with SEZs is disappointing in some extent. In this regard, we believe that the study of the issue of creating and developing special economic zones in the countries of the African continent is relevant, including the 
economic potential that Africa possesses with a competent allocation of resources and attracting foreign investors.

There are many opportunities for the development of diversified business in the region, but they are technologically limited due to the serious industrial weakness of most African states. In this regard, the creation of industrial SEZs with further export of the products of such enterprises is considered the most reasonable way for the economic development of Africa. At best, African governments do not consider various options for their companies to participate in the supply of raw materials to world markets or to gain knowledge through training in the existing production processes taking place in these zones.

\section{PROBLEM STATEMENT: ARE SEZS POSSIBLE IN AFRICA?}

Currently, the largest number of zones are located in developing countries (fig. 1, table 1), with a significant predominance in the Asian region. SEZs can improve market processes in host countries and stimulate economic development.

There is a popular phrase in Africa: "Manufacturing is only for the brave." Recently, such ideas began to be expressed by those investors who decided to risk and invest in Africa, trying to increase country's share in world trade (currently 3\%). Actual lack of infrastructure, bureaucratic barriers, excessive role of trade unions, corruption, high taxes are only part of the problems often faced by producers and investors in Africa. Despite these problems, some recognized experts in the study of SEZs in Africa, particularly - T. Farol, V. Angko, J. Quake and others, argue that production in Africa is on the rise [5,79]; while other economists disagree [10].

In response to such conflicting opinions, African governments have begun creating modern specialized economic zones with incentives for investors.

Since the establishment of the first SEZs in the early 1970s, African governments have failed to attract significant investment, stimulate exports, or sustain industrial development even in half a century of such investment work. During the commissioning of SEZs, problems arise such as misinterpreted incentives for the creation of zones, a significant emphasis on obtaining short-term benefits, poor infrastructure, conflicts of interest between governments and investors, in-country conflicts and political instability, and ecological problems. In fact, the list of problems faced by SEZs in Africa is much more longer.

Considering such a large "baggage" of problems, it is obvious that only courageous investors can engage in production in these SEZs. In particular, as L. Thompson notes, Chinese investors collaborated with the

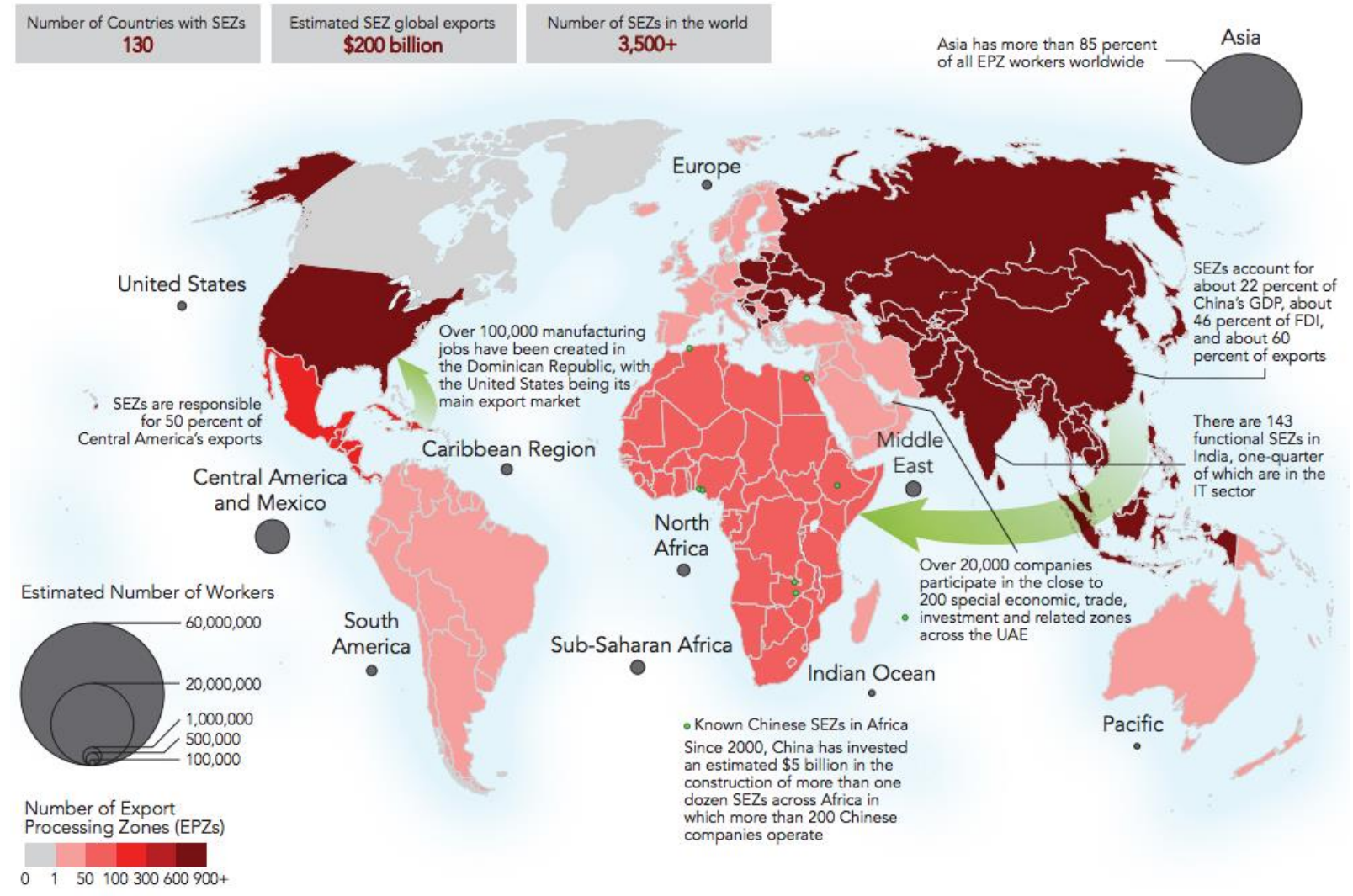

Figure 1 Map of distribution of SEZ in the world [6]. 
Table 1. Nuber of SEZs (by regions), 2019 [6]

\begin{tabular}{|l|c|c|c|}
\hline & Total number of SEZs & $\begin{array}{c}\text { Including those in } \\
\text { development stage }\end{array}$ & $\begin{array}{c}\text { Planned additional } \\
\text { SEZs }\end{array}$ \\
\hline World total & 5383 & 474 & 507 \\
\hline Developed countries & 374 & 5 & - \\
\hline Europe & 105 & 5 & - \\
\hline North America & 262 & - & 502 \\
\hline Developing countries & 4772 & 451 & 419 \\
\hline Asia & 4046 & 371 & - \\
\hline East Asia & 2645 & 13 & - \\
\hline China & 2543 & 13 & 184 \\
\hline Southeast Asia & 737 & 167 & 61 \\
\hline South Asia & 456 & 167 & - \\
\hline India & 373 & 142 & 53 \\
\hline West Asia & 208 & 24 & 24 \\
\hline Africa & 237 & 51 & 5 \\
\hline Latin America and the Caribbean & 486 & 28 & 140 \\
\hline Countries with transition economies & 237 & 18 & 37 \\
\hline Weakly developed countries & 173 & 54 & 10 \\
\hline Least developed countries & 146 & 22 & 8 \\
\hline Island states & 33 & & \\
\hline
\end{tabular}

governments of African countries in the creation of seven SEZs in Africa within the framework of Beijing's "Going Global" trade policy [11].

\section{CAUSES OF THE CRISIS IN THE DEVELOPMENT OF SEZS IN AFRICA}

The guilt for the failure of the economic zones belongs to the governments of African countries. The broad industrial development plans do not cover most zones. As a result, the process for evaluating production and productivity becomes cumbersome. The lack of desire to integrate these zones into general industrial policy remains a problem for almost the entire African continent. African governments have not been able to think ahead of how SEZs can improve their contribution to world trade or link with global supply chains. [12]

Small and medium-sized entrepreneurs in Mauritius, working in the garment, footwear and furniture industries, bear the brunt of competition from those developing countries that also specialize in the production of such products, primarily China and Vietnam, as well as other countries of Southeast Asia because they cannot correspond to value for money. In Ethiopia [13], for example, the government views the SEZ as an industrial zone and has little interest in developing an industrial development strategy.
This leads to another failure of the governments of African countries in terms of the creation and operation of the SEZ. From the outset, investors from China received almost exclusive access to SEZs, requiring little or no foreign investment [12]. Other countries actively investing in Africa mainly choose investment directions not related to the SEZ. However, competent management of investments in SEZs by all countries can significantly increase Africa's share in world production and trade.

SEZs in Africa appeared relatively late, although they have recently been rising. The first African country to establish a SEZ was Mauritius, which passed its SEZ Act in 1970. Around the same time, other countries on the continent - Senegal, Liberia and Ghana - followed suit. However, SEZs were relatively active in Africa only in the 1990s, since the keen interest of the world community and major investors in the 1970s. was addressed to the transformation and development of the countries of East Asia. In reliance on the fact that infrastructural and institutional weaknesses are widely recognized as the main obstacles to economic development in Africa, the introduction of zones that enable African governments to channel their administrative resources and develop the necessary infrastructure in troubled depressed areas is often seen as one of the only pragmatic solutions to address major structural weaknesses $[5,7,14]$. 
There are currently about 237 SEZs which were established in Africa, but some zones are still planning to be opened and are under construction (see table 1). In addition, there are more than 200 zones for one enterprise (or free spots). SEZs are located in 38 out of 54 countries on the continent, with the largest number in Kenya (table 2).

SEZ programs are well developed in the continent's three largest economies - Egypt, Nigeria and South Africa. Many small African countries have created SEZ structures only in the last 10-15 years and, as a rule, have fewer zones.

\section{DEVELOPMENT POTENTIAL OF SEZ IN AFRICA}

SEZs in Africa, especially in sub-Saharan Africa, are created mainly to expand local production and export products of labor-intensive industries with low levels of skill workers (for example, clothing and textiles). However, there are also countries on the continent where SEZs are focused on various sectors and on the creation of products with higher added value. For example, some SEZs in Morocco focus on high technology and the automotive industry [14].

Some countries are betting on attracting investors in SEZs specializing in the production of processed products in order to diversify the structure of exports, which were initially focused on raw resources. For example, in Nigeria, a number of oil refining zones have been established.

L. Thompson's work notes that some of the least developed countries in Africa received financial assistance for the construction of SEZs from foreign investors on the basis of bilateral and multilateral agreements, especially from China [11]. However, financial investments were not the only incentive for the development of zones in Africa. Among the other incentives, we can point such condition as a long-term partnership between countries that brings joint benefits. In 1999, China began working with Africa. Starting in 2006, China planned to put into operation 7 SEZs in Africa; in total, China intends in the next 50 of its zones around the world. So, in 2016, China launched a 10-year project to create an FTZ in Djibouti worth \$ 3.5 billion. The SEZ will be managed by a joint venture consisting of the government of Djibouti (the main shareholder) and three Chinese companies: China Merchants Group, Dalian Port Authority and IZP. Chinese companies plan to further develop their activities to create SEZs in some African countries.

Other countries and development agencies, albeit not so actively as China, have also expanded the investment phenomenon in the African FEZ. In 2015, Turkey signed an agreement with Djibouti on the creation of a free economic zone with an area of 500 hectares, where the Turkish side will invest in the production and exporting of goods to the markets of African countries, in turn, to the relatively developed East African markets. $[4,13]$. In 2018, the state-owned Singapore Enterprise for Cooperation, Trade Facilitation and Trade Efficiency signed an agreement to establish a single electronic window for the SEZ in Nkok, Gabon. [12]

\subsection{Natural resource zones}

In regions that make up a significant part of the economy of such countries, very common options for creating SEZs based on natural resources are used. These structures house enterprises for the processing of raw materials and the production of semi-finished products. The key sources of these commodities are agricultural, fisheries, forestry or mining products. The goal set for themselves by the creators of such zones is the desire to create vertically integrated production from productivity to processing of fossil products with a degree of processing, as well as the growth of exports of processed products. The result of the effective operation of the zones should ideally be a large-scale economic transformation in those African countries where the emphasis is on the development of natural resource zones.

With regard to the specifics of the African region, it should be noted that one of the main characteristics of such zones as natural resource zones, and in the first place. Crucial in achieving this security is a safe transition from subsistence farming to robust agroindustrial development. The types of natural resource

Table 2. African countries with the largest number of SEZs in 2019 [6]

\begin{tabular}{|l|c|}
\hline \multicolumn{1}{|c|}{ Country } & Number of SEZs \\
\hline Kenya & 61 \\
\hline Nigeria & 38 \\
\hline Ethiopia & 18 \\
\hline Egypt & 10 \\
\hline Cameroon & 9 \\
\hline
\end{tabular}


zones for the development of the agro-industrial complex, which are being developed by African countries, rural agro-industrial clusters, agro-industrial parks, agricultural corridors and agro-incubators. The main benefits that residents of agro-industrial zones in Africa will receive are a more developed infrastructure (compared to other mostly depressed territories), simplified customs procedures for processing foreign trade transactions, and a favorable regulatory framework. One illustrative example of the successful development and operation of the resource zone system in agriculture is Dube Agrizone in South Africa, which is part of the Dube Tradeport SEZ. This zone offers world-class equipment and technical support services for the collection, cultivation, packaging and logistics of highvalue perishable food items provided.

Currently in Africa, popular zones specializing in the processing of hydrocarbons, with the aim of contributing to the creation of added value at the local level. For example, in Nigeria, at least 10 SEZs are under construction to facilitate oil and gas processing (among other activities). The flagship free trade zone in Lagos is developing as a multi-disciplinary and logistics hub for the West African sub-region. It is planned that this zone will host oil and petrochemical complexes, as well as agri-food and other processing industries.

\section{CONCLUSIONS}

Summing up the results of the study, we will draw the following main conclusions. SEZs in Africa, as well as their attractiveness to foreign investors, are likely to continue to grow. Impressive achievements of some countries (for example, Gabon, Egypt, Ethiopia) in terms of the results of the SEZ as a springboard for participation in the global value chain is likely to encourage others to follow suit. Many African least developed countries that do not have or have multiple zones (for example, Madagascar, Lesotho, Democratic Republic of the Congo and Rwanda) are planning to create at least one new SEZ.

From an economic point of view, there is currently insufficient linkages between local supply chains and the pace of commissioning of African SEZs. Most African governments need to continue to work actively to develop attractive investment economic and policy measures that would enable local producers to work effectively with foreign SEZ-based enterprises to share knowledge and technology. So far, the interests of the heads of African countries practically do not consider options for the participation of their producers in the supply of raw materials to foreign markets or training their workers in the production processes taking place in their SEZs.

If Africa will seriously consider the possibility of implementing the SEZ in its economic processes, but the continent urgently needs to make adjustments in its economic and political reforms. Otherwise, the current state of affairs will not stimulate industrialization and will not contribute to the active participation of Africa in international economic relations.

\section{AUTHOR'S CONTRIBUTIONS}

The contribution of the authors in the preparation of this article is equal.

\section{REFERENCES}

[1] F. Bost, Free Zones: a State of the Art, The World of Free Zones, Towards a New Global Trade Order, Dubai: World Free Zones Organization, 2016.

[2] S. Frick, A. Rodríguez-Pose and M. Wong, Toward Economically Dynamic Special Economic Zones in Emerging Countries, Economic Geography 95(1) (2019) 30-64. DOI: https://doi.org/10.1080/00130095.2018.1467732

[3] L. Moberg, The political economy of special economic zones, Journal of Institutional Economics 11(01) (2015) 167-190. DOI: https://doi.org/10.1017/S1744137414000241

[4] Trade in Counterfeit Goods and Free Trade Zones: Evidence from Recent Trends. Illicit Trade, Paris: OECD Publishing, 2018.

[5] W. Angko, Analysis of the Performance of Export Processing Zones in Ghana, Journal of Business Administration and Education Vol. 5(1) (2004) 143.

[7] T. Farole, Second Best? Investment Climate and Performance in Africa's Special Economic Zones, World Bank, 2010.

[8] T. Farole and G. Akinci, Special Economic Zones: Progress, Emerging Challenges, and Future Directions, Directions in Development Series, Washington, D.C.: World Bank, 2011.

[9] T. Farole and J. Kweka, Institutional best practices for special economic zones: an application to Tanzania, Africa Trade Policy Notes, No.25. Washington, D.C.: World Bank, 2011.

[10] Special Economic Zones: Performance, Lessons Learned, and Implications for Zone Development, Washington, D.C.: World Bank, FIAS, 2008.

[11] L. Thompson, Alternative South-South development collaboration? The role of China in the Coega special economic zone in South Africa, Public Administration and Development Vol. 39 Issue 4-5 (2019) 193-202. DOI: https://doi.org/10.1002/pad.1869 
[12] R.B. Davies, A. Mazhikeyev, The impact of special economic zones on exporting behavior, Review of Eonomic Analysis Vol. 11 Iss. 1 (2019) 145-174.

[13] P. Giannecchini, I. Taylor, The eastern industrial zones in Ethiopa: catalyst for development? Geoforum Vol. 88 (2018) 28-35. DOI: https://doi.org/10.1016/j.geoforum.2017.11.003

[14]T. Cheng, Special Economic Zones: A Catalyst for International Trade and Investment in Unsettling Times? Journal of World Investment \& Trade 20(1) (2019) 32-67. DOI: https://doi.org/10.1163/22119000-12340122 